\title{
Hubungan Hukum Dan Kekuasaan
}

\author{
Oleh : Salman Luthan \\ Dosen FH UII Yogyakarta \\ E mail:
}

\begin{abstract}
Human being is a social creature which needs each other to fulfill the requirement of live, anywhere he or she lives. And every place of human live have rules to keep the peacefulness and justice among the individuals. These rules or laws were born to be adapted for value expanding in society community compiled by people who have power. Among law and power cannot be dissociated because law made by authority and the authority obtain the power passing the laws.
\end{abstract}

Keywords: Hubungan Hukum, kekuasaan

\section{Pendahuluan}

Dalam kehidupan masyarakat, kekuasaan mempunyai arti penting bagi hukum karena kekuasaan bukan hanya merupakan instrumen pembentukan hukum (law making), tapi juga instrumen penegakan hukum (law enforcement). Pembentukan hukum, khususnya undang-undang, dilakukan melalui mekanisme kekuasaan politik dalam lembaga legislatif di mana kepentingankepentingan kelompok masyarakat yang saling bertentangan diupayakan untuk dikompromikan guna menghasilkan satu rumusan kaidah-kaidah hukum yang dapat diterima semua pihak. Penegakan hukum merupakan upaya untuk mendorong masyarakat agar mentaati aturan-aturan hukum yang berlaku (upaya preventif) dan penjatuhan sanksi hukum terhadap kasuskasus pelanggaran hukum yang terjadi dalam masyarakat (upaya represif).

Hukum juga mempunyai arti penting bagi kekuasaan karena hukum dapat berperan sebagai sarana legalisasi bagi kekuasaan formal lembagalembaga negara, unit-unit pemerintahan, pejabat negara dan pemerintahan. Legalisasi kekuasaan itu dilakukan melalui penetapan landasan hukum bagi kekuasaan melalui aturan-aturan hukum. Di samping itu, hukum dapat pula berperan mengontrol kekuasaan sehingga pelaksanaannya dapat dipertanggungjawabkan secara legal dan etis. 
Karakteristik hubungan hukum dan kekuasaan, khususnya dalam hal legalisasi kekuasaan dan penegakan hukum, dijelaskan oleh Mochtar Kusumaatmadja dalam satu ungkapkan "hukum tanpa kekuasaan adalah angan-angan, dan kekuasaan tanpa hukum adalah kelaliman". Ungkapan tersebut, pada satu sisi, mengandung arti bahwa kaidah-kaidah hukum tidak akan ada manfaatnya jika tidak ditegakkan, dan hukum itu hanya dapat ditegakkan dengan kekuasaan. Pada sisi lain, ungkapan itu bermakna bahwa kekuasaan tanpa landasan hukum adalah kesewenangwenangan.

Namun yang sering menjadi permasalahan adalah tolok ukur legalitas kekuasaan. Apakah setiap kekuasaan yang berdasarkan aturan hukum dapat dikualifikasikan sebagai kekuasaan sah atau legal? Apakah kekuasaan sewenang-wenang yang memiliki landasan hukum harus diterima dan ditaati? Apakah kekuasaan yang sewenang-wenang dapat melahirkan hukum yang adil? Apakah efektivitas penegakan hukum tergantung pada legalitas kekuasaan? Dan apakah kekuasaan legal yang sewenang-wenang dapat menegakkan hukum guna mencapai keadilan?

Meskipun hukum mempunyai hubungan yang sangat erat dengan kekuasaan, tapi studi kekuasaan dalam perspektif hukum masih terbatas sehingga konsep-konsep kekuasaan di dalam ilmu hukum tidak begitu berkembang. Kecenderungan studi hukum lebih terfokus kepada 2 aspek, pertama yaitu hukum dipandang sebagai kaidah yang menjadi pedoman tingkah laku yang bersifat memaksa dan memberikan sanksi kepada orang yang melanggarnya,dan yang kedua hukum dipandang sebagai realitas sosial yang terjadi di masyarakat yang dipraktikkan melalui lembaga peradilan (the living law), adanya pelanggaran-pelanggaran hukum (perilaku pelanggar hukum), dan ketaatan terhadap hukum. Singkatnya, hukum mengandung dua pokok utama, yaitu aturan yang seharusnya dilakukan (das sollen), dan kenyataan yang ada dalam masyarakat (das sein). Namun dalam kenyataannya hanya hukum yang hidup dan pelanggaran hukum yang banyak dikaji, sedangkan ketaatan kepada hukum tidak dianggap sebagai masalah.

Tulisan ini bermaksud mengkaji hubungan dialektis hukum dan kekuasaan. Masalah pokok yang akan dibahas meliputi: bagimanakah kekuasaan dalam konteks hukum, bagaimanakah hubungan dialektis hukum dengan kekuasaan, serta bagaimanakah fungsi kekuasaan terhadap hukum dan fungsi hukum terhadap kekuasaan? 


\section{Esensi Kekuasaan dan Hukum}

\section{A. Esensi Kekuasaan}

Kekuasaan merupakan konsep hubungan sosial yang terdapat dalam kehidupan masyarakat, negara, dan umat manusia. Konsep hubungan sosial itu meliputi hubungan personal di antara dua insan yang berinteraksi, hubungan institusional yang bersifat hierarkis, dan hubungan subjek dengan objek yang dikuasainya. Karena kekuasaan memiliki banyak dimensi, maka tidak ada kesepahaman di antara para ahli politik, sosiologi, hukum dan kenegaraan mengenai pengertian kekuasaan.

Max Weber, ${ }^{1}$ dalam bukunya Wirtschaft und Gesellschaft (1992) mengemukakan bahwa "kekuasaan adalah kemampuan untuk, dalam suatu hubungan sosial, melaksanakan kemauan sendiri sekalipun mengalami perlawanan, dan apa pun dasar kemampuan ini." Perumusan kekuasaan yang dikemukakan Weber dijadikan dasar perumusan pengertian kekuasaan oleh beberapa pemikir lain Misalnya, Strausz-Hupe ${ }^{2}$ mendefinisikan kekuasaan sebagai "kemampuan untuk memaksakan kemauan pada orang lain" Demikian pula pengertian yang dikemukakan oleh C. Wright Mills”, "kekuasaan itu adalah dominasi, yaitu kemampuan untuk melaksanakan kemauan kendatipun orang lain menentang, artinya kekuasaan mempunyai sifat memaksa"

Menurut Talcot Parsons ${ }^{4}$, kekuasaan adalah kemampuan umum untuk menjamin pelaksanaan dari kewajiban-kewajiban yang mengikat oleh unit-unit organisasi kolektif dalam suatu sistem yang merupakan kewajiban-kewajiban yang diakui dengan acuan kepada pencapaian tujuan-tujuan kolektif mereka dan bila ada pengingkaran terhadap kewajiban-kewajiban dapat dikenai oleh sanksi negatif tertentu, siapapun yang menegakkannya. Pengertian ini menitikberatkan kepada kekuasaan

${ }^{1}$ Miriam Budiardjo, “Aneka Pemikiran Tentang Kuasa Dan Wibawa," Jakarta: Sinar Harapan, 1991.hlm. 1. 16. Lihat juga Max Weber, 1982, Wirtschaft und Geselschaft, Tubingen Mohr, 1982.

${ }^{2}$ Ibid

${ }^{3}$ Soelaeman Soemardi, "Pendekatan Terhadap Kejahatan Sebagai Suatu Fenomena Sosial." Lihat juga Miriam Budihardjo,Ibid. Lihat juga Robert Strausz-Hupe, Power and Community, 1956, hlm 12 dan 14.

${ }^{4}$ Talcott Parsons, Oktober, "The Distribution of Power in AmericanSociety." World Politics. 1957, hlm.139. 
publik untuk menegakkan aturan-aturan masyarakat yang bersifat memaksa demi untuk memberikan perlindungan kepada masyarakat.

Di samping pengertian kekuasaan sebagai kemampuan untuk memaksakan kehendak atau kemauan kepada pihak lain, beberapa pakar mengartikan kekuasaan sebagai kemampuan untuk membatasi tingkah laku pihak lain. Harold D.Laswell, ${ }^{5}$ dan Abraham Kaplan mengatakan bahwa "kekuasaan adalah suatu hubungan di mana seseorang atau kelompok orang dapat menentukan tindakan seseorang atau kelompok lain agar sesuai tujuan dari pihak pertama.

Seiring dengan pandangan Laswell dan Kaplan, Van Doorn ${ }^{6}$ mengungkapkan bahwa "kekuasaan adalah kemungkinan untuk membatasi alternatif-alternatif bertindak dari seseorang atau suatu kelompok sesuai dengan tujuan dari pihak pertama". R.J. Mokken merumuskan konsep "Kekuasaan adalah kemampuan dari pelaku (seseorang atau kelompok atau lembaga) untuk menetapkan secara mutlak atau mengubah (seluruhnya atau sebagiannya) alternatif-alternatif bertindak atau alternatif-alternatif memilih, yang tersedia bagi pelakupelaku lain".

Kekuasaan dalam kaitannya dengan masalah kenegaraan, dapat dibedakan ke dalam dua kelompok, yaitu kekuasaan negara dan kekuasaan masyarakat. Kekuasaan negara berkaitan dengan otoritas negara untuk mengatur kehidupan masyarakat secara tertib dan damai. Kekuasaan masyarakat adalah kekuatan/kemampuan masyarakat untuk mengelola dan mengorganisasikan kepentingan individu-individu dan kelompok-kelompok masyarakat yang menjadi anggotanya sehingga interaksi sosial dapat berjalan secara lancar. Ketidakseimbangan diantara keduanya akan mendorong terjadinya kekuasaan hegemonik di mana negara sangat kuat dan masyarakat sangat lemah, sehingga tercipta pola hubungan dominatif dan eksploitatif. Hal ini mengakibatkan negara bukan hanya campur tangan dalam urusan-urusan kenegaraan dan kemasyarakatan, tetapi juga intervensi atas seluruh tindakan masyarakat yang sebenarnya bukan dalam lingkup wewenangnya.

Selain berarti kemampuan untuk mempengaruhi orang lain dan penetapan alternatif-alternatif bertindak, kekuasaan juga mengandung makna sarana pelaksanaan fungsi-fungsi dalam masyarakat dan atas

\footnotetext{
${ }^{5}$ Miriam Budihardjo, Op. Cit., hlm. 20.

${ }^{6}$ Ibid., hlm. 17.
} 
nama masyarakat. ${ }^{7}$ Pelaksanaan fungsi-fungsi dalam masyarakat mencakup pelaksanaan fungsi politik, pelaksanaan fungsi ekonomi, pelaksanaan fungsi sosial dan budaya, pelaksanaan fungsi hukum dan pemerintahan, dan pelaksanaan fungsi-fungsi lainnya. Pelaksanaan fungsi itu bertujuan untuk memperlancar interaksi sosial dan penyelenggaraan kehidupan masyarakat.

Untuk keperluan tulisan ini, kekuasaan diartikan sebagai konsep hubungan sosial dominatif yang menggambarkan adanya suatu kekuatan yang dimiliki oleh seseorang atau satu pranata untuk memaksakan kehendaknya kepada orang lain (termasuk pranata lain) yang dilakukan melalui penetapan perintah-perintah atau pembuatan aturan-aturan tingkah laku sehingga orang lain menjadi tunduk dan patuh terhadap perintah-perintah dan aturan-aturan tingkah laku tersebut.

\section{B. Esensi Hukum}

Mengenai esensi hukum dapat dikemukakan bahwa ada perbedaan pandangan di antara para ahli hukum tentang hukum. Perbedaan pandangan itu dapat dilihat dari pengertian hukum yang mereka kemukakan yang berbeda antara yang satu dengan yang lainnya. Meskipun ada perbedaan pandangan, namun pengertian itu dapat diklasifikasikan dalam empat kelompok.

Pertama, hukum diartikan sebagai nilai-nilai. Misalnya, Victor Hugo yang mengartikan hukum sebagai kebenaran dan keadilan. Sejalan dengan pengertian tersebut, Grotius ${ }^{8}$ mengemukakan bahwa hukum adalah suatu aturan moral tindakan yang wajib yang merupakan sesuatu yang benar. Pembahasan hukum dalam konteks nilai-nilai berarti memahami hukum secara filosofis karena nilai-nilai merupakan abstraksi tertinggi dari kaidah-kaidah hukum.

Kedua, hukum diartikan sebagai asas-asas fundamental dalam kehidupan masyarakat Definisi hukum dalam perspektif ini terlihat dalam pandangan Salmond ${ }^{9}$ yang mengatakan "hukum merupakan kumpulan asas-asas yang diakui dan diterapkan oleh negara di dalam peradilan".

7 Talcott Parsons, Sociological Theory and Modern Society, New York: The Free press, 1967, hlm. 308.

${ }^{8}$ Ahmad Ali, Menguak Tabir Hukum, Jakarta: Chandra Pratama, 1996, hlm. 39.

${ }^{9}$ L.B. Curzon, Jurisprudence, M\&E Handbook, 1979, hlm. 24. 
Ketiga, hukum diartikan sebagai kaidah atau aturan tingkah laku dalam kehidupan masyarakat. Vinogradoff ${ }^{10}$ mengartikan hukum sebagai seperangkat aturan yang diadakan dan dilaksanakan oleh suatu masyarakat dengan menghormati kebijakan dan pelaksanaan kekuasaan atas setiap manusia dan barang. Pengertian yang sama dikemukakan oleh Kantorowich, yang berpendapat bahwa hukum adalah suatu kumpulan aturan sosial yang mengatur perilaku lahir dan berdasarkan pertimbangan.

Keempat, hukum diartikan sebagai kenyataan (das sein) dalam kehidupan masyarakat. Hukum sebagai kenyataan sosial mewujudkan diri dalam bentuk hukum yang hidup (the living law) dalam masyarakat atau dalam bentuk perilaku hukum masyarakat. Perilaku hukum terdiri dari perilaku melanggar hukum (pelanggaran hukum) dan perilaku menaati aturan-aturan hukum.

Perbedaan pandangan di antara ahli hukum bukan hanya mengenai pengertian hukum, tapi juga mengenai hakekat hukum. Perbedaan pandangan mengenai hakekat hukum ini tergambar dari munculnya berbagai mazhab dalam pemikiran hukum. Pertanyaan pokok tentang hakekat hukum berkaitan dengan hukum yang benar, apakah hukum yang benar? Jawaban atas pertanyaan prinsipil tersebut beraneka ragam dan saling kontradiktif.

Dalam paham hukum agama yang teistik, hakekat hukum adalah perintah Allah. Hukum yang benar adalah hukum yang difirmankan dan diperintahkan oleh Tuhan. Menurut doktrin Islam, hukum yang benar adalah hukum Allah yang dirumuskan dalam Qur'an, dan hukum yang disabdakan Rasul dalam hadis. Sedangkan bagi paham sekuler, hakekat hukum tidak ada hubungannya dengan urusan keagamaan dan ketuhanan, tapi merupakan urusan peradilan, kemasyarakatan, dan kenegaraan.

Dalam konteks ini hakekat hukum bisa ditinjau dari empat perspektif, yaitu perspektif otoritas (wewenang), perspektif substantif, perspektif sosiologis, dan perspektif realis. Perspektif otoritas merupakan pandangan paham positivisme yang menempatkan keabsahan hukum pada otoritas pembentukan dan penegakan hukum.

Pemikir positivisme yang cukup berpengaruh, John Austin ${ }^{11}$ mengemukakan bahwa hukum adalah seperangkat perintah, baik

\footnotetext{
${ }^{10}$ Ahmad Ali, Op. Cit., hlm. 34.

${ }^{11} \mathrm{Ibid},$. hlm. 40.
} 
langsung ataupun tidak langsung, dari pihak yang berkuasa kepada warga masyarakatnya yang merupakan masyarakat politik yang independen, di mana otoritasnya (pihak yang berkuasa) merupakan otoritas tertinggi). Definisi yang hampir sama dikemukakan pula oleh Blackstone (Abad XVIII) yang mengungkapkan bahwa hukum adalah suatu aturan tindakan-tindakan yang ditentukan oleh orang-orang yang berkuasa bagi orang-orang yang dikuasai, untuk ditaati.

Berbeda dengan perspektif otoritas, perspektif substantif tidak melihat keabsahan hukum dari sudut otoritas yang membentuk hukum tersebut, tapi dari muatan atau isi yang terkandung dalam kaidah-kaidah hukum tersebut. Pandangan ini tergambar dari pandangan John Locke yang mengemukakan bahwa hukum adalah sesuatu yang ditentukan oleh warga masyarakat pada umumnya tentang tindakan-tindakan mereka, untuk menilai mana yang merupakan perbuatan yang jujur dan mana yang merupakan perbuatan yang curang.

Perspektif historis meninjau keabsahan hukum berdasarkan kebudayaan masyarakat, khususnya dalam jiwa rakyatnya. Von Savigny menggambarkan bahwa keseluruhan hukum terbentuk melalui kebiasaan dan perasaan kerakyatan, yaitu melalui pengoperasian kekuasaan secara diam-diam. Hukum berakar pada sejarah manusia, di mana akarnya dihidupkan oleh kesadaran, keyakinan dan kebiasaan warga masyarakat.

Perspektif sosiologis meninjau keabsahan hukum itu dari sudut kemampuan atau daya kerja hukum mengatur kehidupan masyarakat. Pertanyaan pokoknya adalah, apakah hukum itu dapat berlaku secara efektif untuk mengatur kehidupan masyarakat. Hakekat hukum menurut perspektif sosiologis adalah hukum yang sesuai dengan fakta-fakta sosial. Lundstedt mengemukakan hukum sungguh-sungguh berwujud eksistensi dari fakta-fakta sosial, yang secara keseluruhan berbeda dari sekedar ilusi.

Kaum realis dapat digolongkan ke dalam perspektif sosiologis karena sama-sama berpijak pada realitas sosial. Hakekat hukum menurut pandangan realisisme adalah hukum yang hidup, yaitu hukum yang dipraktekkan oleh pengadilan dalam menyelesaikan sengketa-sengketa dan kasus-kasus hukum yang terjadi dalam masyarakat. Holmes ${ }^{12}$, seorang hakim agung USA yang menjadi pendiri aliran realis, berpendapat "apa yang diramalkan akan diputuskan oleh pengadilan, itulah yang saya

\footnotetext{
${ }^{12}$ L.B. Curzon, Op. Cit., hlm. 27.
} 
artikan sebagai hukum" Pendapat Holmes ini sejalan dengan pandangan Llewellyn yang menyatakan bahwa apa yang diputuskan oleh seorang hakim tentang suatu persengketaan, adalah hukum itu sendiri.

\section{Hubungan Hukum dan Kekuasaan}

Pola hubungan hukum dan kekuasaan ada dua macam. Pertama, hukum adalah kekuasaan itu sendiri. Menurut Lassalle dalam pidatonya yang termashur Uber Verfassungswessen, "konstitusi sesuatu negara bukanlah undang-undang dasar tertulis yang hanya merupakan "secarik kertas", melainkan hubungan-hubungan kekuasaan yang nyata dalam suatu negara"13 Pendapat Lassalle ini memandang konstitusi dari sudut kekuasaan.

Dari sudut kekuasaan, aturan-aturan hukum yang tertuang dalam konstitusi suatu negara merupakan deskripsi struktur kekuasaan yang terdapat dalam negara tersebut dan hubungan-hubungan kekuasaan di antara lembaga-lembaga negara. Dengan demikian, aturan-aturan hukum yang termuat dalam Undang-Undang Dasar (UUD) 1945 merupakan deskripsi struktur kekuasaan ketatanegaraan Indonesia dan hubunganhubungan kekuasaan antara lembaga-lembaga negara. Struktur kekuasaan menurut UUD 1945 menempatkan MPR (Majelis Permusyawaratan Rakyat) dalam hierarki kekuasaan tertinggi. Hierarki kekuasaan di bawah MPR adalah kekuasaan lembaga-lembaga tinggi negara, yaitu presiden, DPR (Dewan Perwakilan Rakyat), DPA (Dewan Pertimbangan Agung), MA (Mahkamah Agung) dan BPK (Badan Pemeriksa Keuangan). UUD 1945 juga mendeskripsikan struktur kekuasan pusat dan daerah. Di samping itu, juga dideskripsikan hubungan antara kekuasaan lembaga tertinggi negara dengan kekuasaan lembaga-lembaga tinggi negara, hubungan kekuasaan di antara lembaga-lembaga tinggi negara, dan hubungan kekuasaan antara pusat dan daerah.

Hakekat hukum dalam konteks kekuasaan menurut Karl Olivecrona tak lain daripada "kekuatan yang terorgansasi", dimana hukum adalah "seperangkat aturan mengenai penggunaan kekuatan", kekerasan fisik atau pemaksaan yang dilakukan oleh penguasa, tidak berbeda dari kekerasan yang dilakukan pencuri-pencuri dan pembunuh-pembunuh. ${ }^{14}$ hlm. 70 .

${ }^{13}$ L.J. van Apeldorn, Pengantar Ilmu Hukum, Jakarta, PT Pradnya Paramita, 1986,

${ }^{14}$ Karl Olivecrona, Law as Fact, Copenhagen-London, 1939, hlm. 123, 169. 
Walaupun kekuasaan itu adalah hukum, namun kekuasaan tidak identik dengan hukum. Mengenai hal ini Van Apeldorn mengemukakan bahwa hukum adalah kekuasaan, akan tetapi ini tidak berarti bahwa hukum tidak lain daripada kekuasaan belaka. Hukum adalah kekuasaan, akan tetapi kekuasaan tidak selamanya hukum. "Might is not right," pencuri berkuasa atas barang yang dicurinya, akan tetapi tidak berarti bahwa ia berhak atas barang itu. ${ }^{15}$

Esensi kekuasaan yang sama dengan hukum tersebut menurut Lassalle adalah kekuasaan fisik, khususnya kekuasaan tentara dan polisi. Namun menurut Van Apeldorn, kekuasaan fisik (materiil) itu bukanlah anasir yang hakiki dari hukum, apalagi anasir yang esensial daripadanya. Kekuasaan fisik itu biasanya hanya menjadi unsur tambahan: sesuatu accesoir, bukan bagian dari hukum. Sebaliknya kekuasaan susila adalah anasir yang esensial dari hukum, yakni kekuasaan yang diperoleh kaidahkaidah hukum dari nilai yang diberikan oleh masyarakat padanya, dan berdasarkan hal mana biasanya kaidah-kaidah itu dapat mengharapkan pentaatan dengan sukarela oleh anggota-anggota masyarakat. ${ }^{16}$

Kekuasaan fisik adalah kekuasaan yang mengandalkan diri pada kekerasan atau paksaan untuk memaksa ketaatan masyarakat kepada aturan hukum yang berlaku dan bila melanggar akan dikenakan sanksi hukum. Kepatuhan masyarakat kepada hukum sangat ditentukan oleh kualitas aparatur pemaksa (polisi dan jaksa) dalam menjalankan tugasnya. Sedangkan kesusilaan adalah kekuasaan batin yang bersumber kepada kesadaran diri manusia mengenai kebaikan, kepatutan dan rasa keadilan. Kepatuhan masyarakat kepada aturan hukum bukan karena ada paksaan dari aparat penegak hukum, tapi berdasarkan kesadaran diri anggota masyarakat yang dengan sukarela mematuhi aturan-aturan hukum.

Kekuasaan dalam lingkup kebijakan publik, khususnya kebijakan hukum (legal policy) menetapkan batasan-batasan tindakan bagi seseorang atau sekelompok orang berkaitan dengan yang dilarang maupun yang dianjurkan, yang disertai dengan sanksi hukum tertentu. Hal ini bertujuan untuk menjamin terselenggaranya ketertiban dan ketentraman bagi hubungan sosial kemasyarakatan.

\footnotetext{
${ }^{15}$ Ibid., hlm. 69.
}

${ }^{16}$ Ibid., hlm. 73. 
Di samping hukum sama dengan kekuasaan, pola hubungan hukum dan kekuasaan yang lain adalah bahwa hukum tidak sama dengan kekuasaan. Artinya, hukum dan kekuasaan merupakan dua hal yang terpisah, tapi ada hubungan yang erat di antara keduanya. Hubungan itu dapat berupa hubungan dominatif dan hubungan resiprokal (timbal balik). Ada tiga bentuk manifestasi hubungan hukum dan kekuasaan dalam konteks ini.

Pertama, hukum tunduk kepada kekuasaan. Maksudnya, hukum bukan hanya menjadi subordinasi kekuasaan, tapi juga sering menjadi alat kekuasaan, dengan kata lain, kekuasaan memiliki supremasi terhadap hukum. Oleh karena itu, definisi hukum yang dikemukakan oleh para ahli menempatkan hukum berada di bawah kontrol kekuasaan.

Pendapat ahli hukum yang menggambarkan pandangan supremasi kekuasaan terhadap hukum dikemukakan oleh Thrasimachus yang mengungkapkan bahwa hukum tak lain daripada apa yang berfaedah bagi orang yang lebih kuat. Pengertian yang hampir sama dikemukakan pula oleh Gumplowicz yang mengungkapkan bahwa hukum bersandar pada penaklukan yang lemah oleh yang lebih kuat; hukum adalah susunan definisi yang dibuat oleh pihak yang kuat untuk mempertahankan kekuasaannya. ${ }^{17}$

Dalam perspektif Marxisme, hukum dibuat tidak untuk melindungi kepentingan seluruh masyarakat, tapi untuk melindungi kepentingan kelompok elit. Hukum adalah alat kaum kapitaslis untuk melindungi kepentingannya dalam melakukan kegiatan bisnis, dan alat penguasa untuk mempertahankan kekuasaannya. Hukum berpihak kepada pihak yang berkuasa dan kaum kapitalis.

Kedua, kekuasaan tunduk kepada hukum. Artinya, kekuasaan berada di bawah hukum dan hukum yang menentukan eksistensi kekuasaan. Dalam pemikiran hukum, tunduknya kekuasaan kepada hukum merupakan konsep dasar dalam penyelenggaraan ketatanegaraan. Konsep itu dirumuskan dalam terminologi supremasi hukum (supreme of law).

Supremasi hukum berarti bahwa hukum merupakan kaidah tertinggi untuk mengatur kehidupan bermasyarakat, berbangsa dan bernegara. Hukum sebagai kaidah tertinggi muncul dalam konsep norma dasar negara (staats fundamental norm) atau grund norm menurut pemikiran Hans

\footnotetext{
${ }^{17}$ Ibid., hlm. 70.
} 
Kelsen. Di samping itu, supremasi hukum juga berarti bahwa penggunaan kekuasaan untuk menjalankan kehidupan ketatanegaraan dan roda pemerintahan harus berdasarkan kepada aturan hukum. Tanpa landasan hukum, kekuasaan tidak memiliki legalitas.

Pada prinsipnya supremasi hukum tidak lain dari rule of law, sehingga dalam suatu negara hukum harus terdapat supremasi hukum. Menegakkan supremasi hukum tentunya harus ada rule of law (Loebby loqman, Kompas 23-9-1999). Rule of law adalah suatu konsep yang dipergunakan supaya negara dan pemerintahnya, termasuk warga negara tidak melakukan tindakan kecuali berdasarkan hukum.

Timothy O'hogan dalam The End of Law dan A.V. Dicey dalam Law and the Constitution menyebutkan prinsip-prinsip utama negara hukum dalam kaitan tegaknya supremasi hukum. Prinsip-prinsip tersebut meliputi pemerintahan berdasarkan hukum dan menghindarkan kekuasaan yang sewenang-wenang, prinsip persamaan di depan hukum (equality before the law), perlindungan hak asasi manusia (HAM), dan adanya peradilan yang bebas dan independen.

Ketiga, ada hubungan timbal balik (simbiotik) antara hukum dan kekuasaan. Dalam hal ini hubungan hukum dan kekuasaan tidak bersifat dominatif di mana yang satu dominan atau menjadi faktor determinan terhadap yang lain, tapi hubungan pengaruh mempengaruhi yang bersifat fungsional, artinya hubungan itu dilihat dari sudut fungsi-fungsi tertentu dan dapat dijalankan di antara keduanya. Dengan demikian, kekuasaan memiliki fungsi terhadap hukum, dan sebaliknya hukum mempunyai fungsi terhadap kekuasaan.

\section{Kekuasaan Dalam Konteks Hukum}

Kekuasaan dalam konteks hukum berkaitan dengan kekuasaan negara, yaitu kekuasaan untuk mengatur dan menyelenggarakan kehidupan bermasyarakat dan bernegara yang meliputi bidang legislatif, eksekutif dan yudikatif. Pengaturan dan penyelenggaraan kehidupan bermasyarakat dan bernegara itu mencakup pengaturan dan penyelenggaraan di tingkat pusat dan di tingkat daerah. Dengan demikian, kekuasaan merupakan sarana untuk menjalankan fungsi-fungsi pokok kenegaraan guna mencapai tujuan negara.

Kekuasaan dalam konteks hukum meliputi kedaulatan, wewenang atau otoritas, dan hak. Ketiga bentuk kekuasaan itu memiliki esensi dan 
ciri-ciri yang berbeda satu sama lain, dan bersifat hirarkis.

Kekuasaan tertinggi adalah Kedaulatan, yaitu kekuasaan negara secara definitif untuk memastikan aturan-aturan kelakuan dalam wilayahnya, dan tidak ada pihak, baik di dalam maupun di luar negeri, yang harus dimintai ijin untuk menetapkan atau melakukan sesuatu. Kedaulatan adalah hak kekuasaan mutlak, tertinggi, tak terbatas, tak tergantung, dan tanpa kecuali ${ }^{18}$.

Kedaulatan atau souvereignity adalah ciri atau atribut hukum dari negara-negara; dan sebagai atribut negara dia sudah lama ada, bahkan ada yang berpendapat bahwa kedaulatan itu mungkin lebih tua dari konsep negara itu sendiri ${ }^{19}$ Dalam teori kenegaraan, ada empat bentuk kedaulatan sebagai pencerminan kekuasaan tertinggi dalam suatu negara. Keempat bentuk kedaulatan itu adalah kedaulatan Tuhan (Godsouvereiniteit), kedaulatan negara (staatssouvereiniteit), kedaulatan hukum (rechtssouvereiniteit), dan kedaulatan rakyat (volkssouvereiniteit) ${ }^{20}$

Dalam kedaulatan Tuhan, kekuasaan terletak pada sumber kekuasaan yang berasal dari Tuhan. Menurut paham kedaulatan negara, kedaulatan itu ada pada negara, dan dalam kedaulatan hukum, yang berdaulat itu bukan Tuhan dan bukan negara, tapi adalah hukum itu sendiri. Dalam kedaulatan rakyat, yang berdaulat itu adalah rakyat, dimana rakyat memberikan kekuasaannya kepada pemerintah melalui sistem pemilihan umum.

Bentuk kedua kekuasaan dalam konteks hukum adalah wewenang. Wewenang berasal dari bahasa Jawa yang mempunyai dua arti, yaitu pertama, kuasa (bevoegdheid) atas sesuatu. Kedua, serangkaian hak yang melekat pada jabatan atau seorang pejabat untuk mengambil tindakan yang diperlukan agar tugas pekerjaan dapat terlaksana dengan baik, kompetensi, yurisdiksi, otoritas ${ }^{21}$.

Adalah ciri khas negara bahwa kekuasaannya memiliki wewenang. Maka kekuasaan negara dapat disebut otoritas atau wewenang. Otoritas atau wewenang adalah "kekuasaan yang dilembagakan", yaitu kekuasaan

${ }^{18}$ Magnis Suseno, Etika Politik, Jakarta, PT Gramedia, 1988, hlm. 53

${ }^{19}$ Fred Iswara, Pengantar Ilmu Politik, Dhwiwantara, 1964, hlm. 92.

${ }^{20}$ Sri Soemantri, Masalah Kedaulatan Rakyat Berdasarkan UUD 1945, Lihat juga Padmo Wahyono (ed), Masalah Ketatanegaraan Indonesia Dewasa Ini, Ghalia Indonesia, 1984, hlm. 67.

${ }^{21}$ Andi Hamzah, Kamus Hukum, Ghalia Indonesia, 1986, hlm. 633. 
yang defakto menguasai, melainkan juga berhak menguasai. Wewenang adalah kekuasaan yang berhak menuntut ketaatan, jadi berhak memberikan perintah ${ }^{22}$.

Bentuk ketiga kekuasaan dalam hukum adalah hak. Salmond merumuskan hak sebagai kepentingan yang diakui dan dilindungi oleh hukum. Rumusan yang hampir sama dikemukakan oleh Allend yang menyatakan bahwa hak itu sebagai suatu kekuasaan berdasarkan hukum yang dengannya seorang dapat melaksanakan kepentingannya (The legally guaranteed power to realise an interest). Sedangkan menurut Holland hak itu sebagai kemampuan seseorang untuk mempengaruhi perbuatan atau tindakan seseorang tanpa menggunakan wewenang yang dimilikinya, tetapi didasarkan atas suatu paksaan masyarakat yang terorganisasi ${ }^{23}$

Definisi hak menurut Holmes ${ }^{24}$ adalah "nothing but permission to exercise certain natural powers and upon certain conditions to obtain protection, restitution, or compensation by the aid of public force". Hak dapat pula diartikan sebagai kekuasaan yang dipunyai seseorang untuk menuntut pemenuhan kepentingannya yang dilindungi oleh hukum dari orang lain, baik dengan sukarela maupun dengan paksaan.

Dengan mengacu kepada beberapa pengertian tersebut dapat diidentifikasikan ciri-ciri hak. Menurut Fitzgerald ${ }^{25}$ (1966:221), ciri-ciri yang melekat pada hak adalah:

a. hak itu dilekatkan pada seseorang yang disebut sebagai pemilik atau subjek dari hak itu. Ia juga disebut sebagai orang yang memiliki titel atas barang yang menjadi sasaran hak.

b. Hak itu tertuju pada orang lain, yaitu yang menjadi pemegang kewajiban di mana antara hak dan kewajiban terdapat hubungan korelatif.

c. Hak yang ada pada seseorang mewajibkan pihak lain utnuk melakukan (monisson) atau tidak melakukan (omission) sesuatu perbuatan. Hal ini dapat disebut sebagai isi dari hak.

d. Perbuatan atau omission itu menyangkut sesuatu yang dapat disebut sebagai objek dari hak.

e. Setiap hak menurut hukum itu mempunyai titel, yaitu suatu peristiwa tertentu yang merupakan alasan melekatnya hak itu pada pemiliknya.

\footnotetext{
${ }^{22}$ Suseno, Op.Cit., hlm. 53.

${ }^{23}$ Lili Rasjidi, Dasar-Dasar Filsafat Hukum, Rajawali, 1988, hlm. 45.

${ }^{24}$ Ahmad Ali, Op. Cit., hlm. 243.

${ }^{25}$ Ibid., hlm. 244.
} 
Pengakuan hukum terhadap hak seseorang mengandung konsekuensi adanya kewajiban pada pihak atau orang lain. Hal itu bisa terjadi karena hubungan hak dan kewajiban bersifat resiprokal atau timbal balik. Hubungan hak dan kewajiban terjadi dalam konsep hubungan hukum, terutama dalam pelaksanaan hubungan hukum (hukum subjektif). Kewajiban adalah suatu perintah hukum yang mengharuskan seseorang untuk memenuhi suatu hal yang menjadi hak orang lain atau melaksanakan perbuatan tertentu.

\section{Fungsi Dialektis Hukum dan Kekuasaan}

Fungsi dialektis hukum dan kekuasaan adalah fungsi timbal balik antara hukum dan kekuasaan. Fungsi hukum dan kekuasaan meliputi fungsi kekuasaan terhadap hukum dan fungsi hukum terhadap kekuasaan. Pembahasan pendahuluan akan mendeskripsikan fungsi kekuasaan terhadap hukum, dimana ada tiga macam fungsi kekuasaan terhadap hukum.

Pertama, kekuasaan merupakan sarana untuk membentuk hukum, khususnya pembentukan undang-undang (law making). Kekuasaan untuk membentuk hukum dinamakan kekuasaan legislatif (legislative power), yang merupakan kekuasaan parlemen atau badan perwakilan.

Namun dalam perkembangannya, pembentukan undang-undang tidak lagi menjadi monopoli parlemen, tapi kerjasama antara parlemen dan pemerintah. Bahkan kecenderungan di berbagai negara menunjukkan lebih besarnya peran pemerintah dalam pembentukan undang-undang. Hal itu bisa terjadi karena pemerintah mempunyai tenaga ahli yang banyak dalam birokrasi pemerintahan guna menyiapkan konsep atau rancangan undang-undang, yang merupakan produk hukum yang bersifat umum dan mengikat seluruh warganegara.

Fungsi parlemen juga mengalami perkembangan dan pergeseran. Sekarang, fungsi pokok parlemen tidak hanya sebagai badan pembuat undang-undang, namun juga perlu dilihat sebagai media komunikasi antara rakyat dan pemerintah, serta berfungsi sebagai jalur rekruitmen kepemimpinan politik sekaligus sebagai badan pengelola konflik yang berkembang di masyarakat. ${ }^{26}$

\footnotetext{
${ }^{26}$ Bambang Cipto, Dewan Perwakilan Rakyat, Rajawali, 1995, hlm. 10.
} 
Namun otoritas pembentukan ketentuan hukum yang bersifat umum bukan hanya menjadi kekuasaan legislatif, tapi juga menjadi wewenang badan peradilan, khususnya sistem hukum Anglosaxon yang mengakui yurisprudensi sebagai sumber hukum pokok. Yurisprudensi menjadi acuan penyelesaian kasus-kasus yang sejenis, sehingga bersifat umum. Dengan demikian, kekuasaan apa saja yang mempunyai otoritas pembentukan hukum dipengaruhi pula sistem hukumnya.

Kedua, kekuasaan merupakan alat untuk menegakkan hukum. Penegakan hukum adalah suatu proses mewujudkan keinginan-keingian hukum menjadi kenyataan. Yang disebut sebagai keinginan-keinginan hukum di sini tidak lain adalah pikiran-pikiran badan pembuat undangundang yang dirumuskan dalam peraturan-peraturan hukum. ${ }^{27}$

Penegakan hukum bukan sekedar menerapkan aturan-aturan hukum formal saja, tapi juga mengkaitkan secara langsung aturan-aturan hukum itu dengan semangat atau spirit yang melatarbelakangi lahirnya aturanaturan tersebut. Penegakan hukum yang semata-mata menegakkan aturan formal tanpa mengkaitkannya secara langsung dengan semangat yang terkandung dalam aturan akan berlangsung dengan cara yang sangat mekanismatik. Padahal tuntutan penegakan hukum tidak terbatas pada pelembagaan prosedur dan mekanisme, tapi juga pada penerapan nilai-nilai substantifnya. ${ }^{28}$

Kekuasaan sebagai alat untuk menegakkan hukum merupakan ororitas negara yang kemudian didistribusikan kepada institusi-institusi formal yang secara operasional melaksanakan fungsi penegakan hukum. Salah satunya didistribusikan kepada kepolisian, sebagai lembaga yang akan mendorong masyarakat untuk mentaati aturan-aturan hukum dan mencegah masyarakat dari pelanggaran hukum (penegakan hukum secara preventif), agar tercipta ketertiban dan ketenteraman masyarakat.

Di samping itu, otoritas negara untuk menegakkan hukum diberikan kepada badan peradilan (kekuasan yudikatif) untuk melakukan proses peradilan terhadap kasus-kasus pelanggaran yang terjadi dalam masyarakat (penegakan hukum secara represif). Penegakan hukum secara represif bertujuan untuk mempertahankan legalitas aturan hukum dengan cara menghukum para pihak yang melanggar hukum.

\footnotetext{
${ }^{27}$ Satjipto Rahardjo, Masalah Penegakan Hukum, Sinar Baru, hlm. 24.

${ }^{28}$ Salman Luthan, "Penegakan Hukum", 1994.
} 
Ketiga, kekuasaan merupakan media untuk melaksanakan hukum. Adapun yang dimaksud dengan pelaksanaan hukum adalah upaya menjalankan (eksekusi) putusan pengadilan yang sudah mempunyai kekuatan hukum tetap. Putusan badan peradilan tidak akan banyak artinya bagi kehidupan masyarakat jika tidak dilaksanakan secara konsekwen dan konsisten. Otoritas eksekusi merupakan kewenangan kejaksaan dan pengadilan.

Mengenai fungsi hukum terhadap kekuasaan ada empat macam. Hukum adalah media untuk melegalisasi kekuasaan. Legalisasi hukum terhadap kekuasaan berarti menetapkan keabsahan kekuasaan dari segi yuridisnya. Setiap kekuasaan yang memiliki landasan hukum secara formal memiliki legalitas. Namun yang sering menjadi masalah adalah bila kekuasaan yang legal itu adalah kekuasaan yang sewenang-wenang, tidak patut, dan tidak adil. Hal itu sebenarnya merupakan masalah legitimasi kekuasaan, yaitu pengakuan masyarakat terhadap keabsahan kekuasaan.

Legalisasi hukum terhadap kekuasaan mencakup legalisasi terhadap kekuasaan, kedaulatan, wewenang, dan hak. Legalisasi kekuasan dapat diberikan kepada lembaga, jabatan, dan orang. Legalisasi kekuasaan bagi lembaga misalnya, bagi negara, lembaga-lembaga negara, unit-unit dalam lembaga-lembaga negara, unit-unit pemerintahan, dan lembaga kemasyarakatan. Legalisasi kekuasaan bagi pejabat misalnya, kewenangan presiden, kewenangan gubernur, dan kewenangan bupati. Sedangkan legalisasi hukum bagi orang adalah pemberian atau pengakuan hak bagi seseorang. Misalnya, hak milik, hak cipta, hak usaha, dan sebagainya.

Kekuasaan yang dilegalisasi hukum belum tentu kekuasaan atau wewenang yang adil dan patut. Oleh karena itu, agar legalitas hukum sejalan dengan prinsip-prinsip keadilan dan kepatutan, maka legalitas kekuasaan juga harus didukung oleh legitimasi etis yang bersandarkan pada persetujuan masyarakat terhadap kekuasaan.

Fungsi hukum terhadap kekuasaan yang lain adalah untuk mengatur dan membatasi kekuasaan. Hubungan-hubungan kekuasaan dalam penyelenggaraan negara harus diatur sedemikian rupa supaya tidak menimbulkan ambiquitas dan paradoksal di antara kekuasaan-kekuasaan negara yang ada atau antara kekuasaan pejabat yang satu dengan kekuasaan pejabat yang lain. Karena hal ini bukan hanya akan menimbulkan ketidakjelasan wewenang dan pertanggungjawabannya, tapi juga akan melahirkan ketidaksinkronan dan ketidakpastian hukum. 
Untuk menghindari terjadinya ambiquitas dan paradoksal pengaturan kekuasaan, maka pengaturan kekuasaan harus dilihat dalam konteks satu sistem hukum. Pendisitribusian wewenang dalam bidang hukum tertentu harus disinkronkan dengan pengaturan wewenang dalam bidang hukum lainnya. Misalnya, harus ada sinkronisasi kewenangan antara kewenangan dalam bidang hukum tata negara dengan kewenangan dalam bidang hukum pemerintahan.

Selain fungsi melegalisasi dan mengatur kekuasaan, fungsi hukum terhadap kekuasaan yang lain adalah membatasi kekuasaan. Pembatasan kekuasaan dapat dilakukan secara sistemik, organik dan yuridis. Pembatasan kekuasaan dimaksudkan untuk menghindari terjadinya penumpukan atau sentralisasi kekuasaan pada satu tangan atau pada satu lembaga. Sentralisasi kekuasaan akan mendorong kepada otoritarianisme dalam penyelenggaraan negara dan penyalahgunaan kekuasaan (abuse of power).

Menurut Bertrand Russel, sistem yang paling baik untuk mengontrol kekuasaan adalah sistem demokrasi. Demokrasi dianggap sebagai sistem terbaik bukan hanya karena adanya konsep pemisahan kekuasaan negara secara seimbang, tapi juga karena dimungkinkan untuk selalu mengoreksi kekuasaan tersebut.

Pembatasan kekuasaan secara organik dilakukan dengan membentuk institusi-institusi pengawasan bagi pelaksanaan kekuasaan, baik yang bersifat formal maupun yang bersifat informal. Sedangkan pembatasan kekuasaan secara yuridis dilakukan melalui perumusan wewenang secara jelas mengenai lingkup wewenang itu, limitasi dan pertanggungjawabannya.

Akhirnya, fungsi hukum terhadap kekuasaan adalah untuk meminta pertanggungjawaban kekuasaan. Menurut Marion Levy, "kekuasaan selalu menyimpulkan imbangannya oleh tanggung jawab, yang berarti pertanggungjawaban dari individu-individu atau golongan-golongan lainnya atas tindakan-tindakannya sendiri dan tindakan-tindakan orangorang lain." 29

Pertanggungjawaban kekuasaan dalam konteks hukum adalah untuk menjaga agar penggunaan kekuasaan dan mekanismenya sesuai dengan tujuan pemberian kekuasaan tersebut. Penyalahgunaan kekuasaan dapat dimintakan pertanggungjawaban hukum. Penyalahgunaan

${ }^{29}$ Soemardi, Op. Cit., hlm. 32-33. 
kekuasaan dalam bidang hukum administrasi dapat dilakukan melalui proses peradilan tata usaha negara, penyalahgunaan kekuasaan yang merugikan kepentingan seseorang atau masyarakat dapat digugat memalui peradilan perdata. Penyalahgunaan kekuasaan yang masuk kategori tindak pidana dapat dituntut secara pidana. Demikianlah pokokpokok pemikiran tentatif mengenai hubungan dialektis hukum dan kekuasaan.

\section{Penutup}

Berdasarkan deskripsi di atas dapat ditarik tiga simpulan. Pertama, kekuasaan adalah suatu konsepsi hubungan sosial antara dua pihak atau dua institusi yang bersifat saling pengaruh mempengaruhi, dominatif atau eksploitatif. Kedua, hakekat hukum dapat ditinjau dari sudut otoritas yang membentuknya, substansinya dan daya kerjanya dalam mengatur masyarakat.

Ketiga, dialektika hukum dan kekuasaan melahirkan dua pola hubungan, yaitu hukum identik dengan kekuasaan dan hukum tidak sama dengan kekuasaan. Pola hubungan hukum identik dengan kekuasaan merefleksikan diri dalam bentuk kedaulatan, otoritas, wewenang, dan hak. Sedangkan pola hubungan hukum tidak sama dengan kekuasaan memunculkan tiga pola hubungan: supremasi kekuasaan terhadap hukum, supremasi hukum terhadap kekuasaan, dan hubungan simbiotik hukum dan kekusaan.

Hubungan simbiotik hukum dan kekuasaan melahirkan hubungan fungsional di antara keduanya, dimana kekuasaan mempunyai fungsi tertentu terhadap hukum, dan hukum juga mempunyai fungsi tertentu terhadap kekuasaan. Kekuasaan mempunyai fungsi sebagai alat untuk membentuk hukum, menegakkan hukum, dan melaksanakan hukum. Sedangkan fungsi hukum terhadap kekuasaan meliputi alat untuk melegalisasi atau menjustifikasi kekuasaan, alat untuk mengatur dan mengontrol kekuasaan, dan alat untuk mengawasi dan mewadahi pertanggungjawaban kekuasaan. 


\section{Daftar Pustaka}

Ahmad Ali, Menguak Tabir Hukum. Chandra Pratama. Jakarta: 1996

Andi Hamzah, Kamus Hukum, Ghalia Indonesi. Jakarta. 1986

Bambang Cipto. Dewan Perwakilan Rakyat, Rajawali. Jakarta:1995

Frans Magnis Suseno, Etika Politik, PT Gramedia. Jakarta:1988

Fred Iswara, Pengantar Ilmu Politik, Dhwiwantara.1964.

Karl Olivecrona, Law as Fact, Copenhagen-London: 1939.

L.B. Curzon.. Jurisprudence. M\&E Handbook. 1979

Lili Rasjidi,. Dasar-Dasar Filsafat Hukum, Rajawali. Jakarta: 1988

L.J. van Apeldorn, Pengantar Ilmu Hukum, PT Pradnya Paramita. Jakarta: 1986

Max Weber, Wirtschaft und Geselschaft. Tubingen Mohr. 1982.

Miriam Budiardjo, Aneka Pemikiran Tentang Kuasa Dan Wibawa. Sinar Harapan. Jakarta: 1991

Padmo Wahyono (ed), Masalah Ketatanegaraan Indonesia Dewasa Ini, Ghalia Indonesia. Jakarta: 1984.

Robert Strausz-Hupe.Power and Community. 1956

Salman Luthan, Penegakan Hukum, FH UII Yogyakarta: 1994

Satjipto Rahardjo. Masalah Penegakan Hukum, Sinar Baru. Jakarta 1984

Sri Soemantri, Masalah Kedaulatan Rakyat Berdasarkan UUD 1945, 1984

Soelaeman Soemardi, Pendekatan Terhadap Kejahatan Sebagai Suatu Fenomena Sosial. 1984

Talcott parsons, The Distribution of Power in AmericanSociety. World Politics. 1957 , Sociological Theory and Modern Society. The Free press. New York: 1967 